\title{
Initial juvenile size and environmental severity: influence of predation and wave exposure on hatching size in Nucella ostrina
}

\author{
Louis A. Gosselin ${ }^{1, *}$, Renata Rehak ${ }^{1}$ \\ ${ }^{1}$ Department of Biological Sciences, Thompson Rivers University, 900 McGill Rd, Kamloops, British Columbia V2C 5N3, \\ Canada \\ ${ }^{2}$ Department of Biology, University of Victoria, PO Box 3020, Station CSC, Victoria, British Columbia V8W 3N3, Canada
}

\begin{abstract}
According to life history theory, offspring survival increases with offspring size, mainly because large offspring are more resistant to environmental stress. Populations and species living in habitats with severe environmental conditions have therefore been predicted to produce larger offspring than populations in more benign environments. We studied 10 populations of the rocky intertidal gastropod Nucella ostrina in Barkley Sound, Canada, to determine the extent of variation in average hatching size at a small spatial scale (the sites being $\leq 10 \mathrm{~km}$ apart), and to determine the influence on hatching size of 2 components of environmental stress: predation and wave exposure. In a 3 yr study of these 10 populations, average shell length of newly hatched snails differed by 15 to $25 \%$ among the populations in a given year, and estimated total organic carbon per hatchling varied by 97 to $210 \%$. These are considerable differences given the proximity of these populations. The relative differences among populations were broadly consistent over the 3 years of the study, some populations consistently producing larger average hatching sizes than other populations. Based on the abundance and size structure of the predator populations at 4 of these field sites, predation pressure was predicted to favour different average $N$. ostrina hatching sizes at these sites: large at 2 sites and small at 2 sites. However, the average hatching size of $N$. ostrina populations at those sites was not consistent with that prediction, suggesting predation pressure may not have been an important determinant of hatching size. This is a surprising finding, as predation is often considered to be a major cause of early juvenile mortality and thus an important selective pressure influencing the evolution of early juvenile traits. However, average population hatching size did correlate with the relative degree of wave exposure of the site, indicating that either wave action itself or factors covarying with wave action have a substantial influence on initial juvenile size in this species.
\end{abstract}

KEY WORDS: Offspring size · Life history · Early juveniles · Mortality factors · Interpopulation variation · Selective pressures

\section{INTRODUCTION}

The body size of a marine invertebrate at the onset of juvenile life (initial juvenile size) can be an important determinant of the individual's subsequent performance. Individuals starting juvenile life with a large size often (but not always, see Moran \& Emlet 2001) have higher survival and growth than smaller individuals, as shown in urchins (Emlet \& Hoegh-Guldberg
1997), intertidal gastropods (Rivest 1983, Moran 1999, Moran \& Emlet 2001), mussels (Phillips 2002), barnacles (Thiyagarajan et al. 2003, Emlet \& Sadro 2006), and ascidians (Marshall \& Keough 2003, 2005). Similar findings have also been reported for inland isopods (Tsai \& Dai 2001) and for terrestrial spiders (Walker et al. 2003).

The higher survival of individuals with large initial body sizes has been associated with a greater ability to 
survive environmental stress (Spight 1976a). For example, large juvenile gastropods are less susceptible to predation, starvation, and physical stresses than smaller juveniles (Spight 1976a, Gosselin 1997, RayCulp et al. 1999). Correspondingly, the performance advantage of a larger initial juvenile size might be greater in habitats with severe environmental conditions than in benign environments (Spight 1976a, Moran \& Emlet 2001, Räsänen et al. 2005). If so, an evolutionary response to these conditions would result in a correlation between environmental severity and average initial juvenile size for populations located along a gradient of environmental severity (Spight 1976a).

Testing the hypothesis of a relationship between initial juvenile size and environmental severity requires knowledge of what constitutes a severe environment for an early juvenile. Spight (1976a) suggested predation as a component of environmental severity for early juvenile benthic invertebrates. He proposed that in habitats where predation pressure on small juveniles is higher than on large juveniles, the evolution of large initial juvenile sizes would be favoured. Spight's hypothesis that predation pressure can influence the evolution of initial juvenile size in a population has since been cited by other studies to help elucidate patterns of variation in initial juvenile size (Rivest 1983, Gosselin 1997, Etter 1989, Moran 1999, Rex et al. 1999). Does predation pressure indeed constitute a sufficiently strong selective pressure to be an important determinant of initial juvenile size in benthic marine invertebrates? Predators do kill some early juvenile benthic invertebrates in the field (see review by Gosselin \& Qian 1997), and a larger body size can reduce a juvenile's vulnerability to predators (e.g. in lobsters Panulirus argus, Smith \& Herrnkind 1992; queen conch Strombus gigas, Ray-Culp et al. 1999; and the intertidal snail Nucella ostrina [previously known as N. emarginata (northern), see Marko et al. 2003], Gosselin 1997). However, the importance of predation as a cause of early juvenile mortality relative to other mortality factors, and thus its importance as a selective pressure, remains unknown (Gosselin \& Qian 1997). Similarly, few studies have examined evolutionary changes specifically in response to predation pressure on early juveniles.

In a study of ontogenetic changes in juvenile Nucella ostrina, Gosselin (1997) reported sharply decreasing susceptibility of $N$. ostrina juveniles to predators with increasing juvenile size at 2 field sites, but very little change in predation pressure with juvenile size at a third site. He predicted that if these differences among sites in predation pressure have been persistent, and if predation pressure is indeed an important determinant of hatching size as suggested by Spight (1976a), then hatching size in $N$. ostrina populations should be larger at the first 2 sites than at the third site. One goal of the present study was therefore to test that prediction by documenting interpopulation variation in hatching size in N. ostrina as a function of local predation pressure, and thus clarify the relationship between predation pressure and offspring size.

Predation is not the only factor that can contribute to environmental severity. In intertidal habitats, several factors that influence early juvenile survival and growth vary along a gradient of wave exposure. Consequently, intensity of wave action or factors correlating with wave action might also contribute to environmental severity for the early juvenile. For instance, early juveniles are vulnerable to desiccation stress and thermal extremes (Gosselin \& Qian 1997) and, for a given intertidal height, these factors are inversely related to intensity of wave exposure due to wave wash and spray of the intertidal zone at low tide in wave-exposed habitats (Dayton 1971, Etter 1988). If desiccation or thermal stress are important causes of early juvenile mortality, then wave-protected shores might be the most severe habitats for early juveniles (Spight 1976a, Moran \& Emlet 2001), and initial juvenile sizes should be greater on wave-protected shores than on wave-exposed shores (Etter 1989). However, other mortality factors increase in severity with wave exposure, such as water turbulence and impacts by waves and water-borne debris; a larger body size might reduce vulnerability to these factors (Shanks \& Wright 1986), favouring a larger initial juvenile size on wave-exposed shores. The relationship between initial juvenile size and wave exposure is poorly understood and thus constitute another objective of this study.

We examined variation in hatching size among populations of Nucella ostrina. An important reason for choosing $N$. ostrina is that it has no planktonic stage in its life cycle: dispersal is therefore mostly limited to the crawling movements of juveniles and adults (Gosselin \& Chia 1995a). Any 2 populations of $N$. ostrina that are isolated by open water or areas of soft sediment intertidal habitat, or even populations that are simply a few hundred metres apart, are therefore likely to experience limited gene flow, potentially allowing divergence of traits such as initial juvenile size. The specific objectives of this study were therefore to: (1) determine whether significant interpopulation variation in hatching size exists among $N$. ostrina populations separated by short distances $(\leq 10 \mathrm{~km})$ relative to the distribution range of the species, (2) to test the hypothesis that predation pressure is a determinant of hatching size in N. ostrina populations, and (3) determine the relationship between hatching size and wave exposure. 


\section{MATERIALS AND METHODS}

Study organism and sites. Female Nucella ostrina deposit embryos as well as nurse eggs in capsules, and attach clutches of 3 to 15 egg capsules to rock or shell surfaces. Embryos feed on nurse eggs during encapsulated development, and emerge from the capsules as early juvenile snails. Hatching size is dependent on the number of nurse eggs consumed by the embryo (Spight 1976b, Rivest 1983), correlates strongly with hatchling organic content, and influences early juvenile survivorship (Moran \& Emlet 2001).

The present study was conducted in Barkley Sound on the west coast of Vancouver Island, British Columbia, Canada, during the summer months of 1999, 2000 and 2001 when most hatching of Nucella ostrina occurs in this region (Gosselin 1994). Egg capsules were collected from 10 sites in Barkley Sound: Ross Islets $\left(48^{\circ} 52^{\prime} 20^{\prime \prime} \mathrm{N}, 1^{\circ} 05^{\circ} 44^{\prime \prime} \mathrm{W}\right)$, Dixon Island sheltered $\left(48^{\circ} 51^{\prime} 14^{\prime \prime} \mathrm{N}, 125^{\circ} 07^{\prime} 01^{\prime \prime} \mathrm{W}\right)$, Dixon Island exposed $\left(48^{\circ} 51^{\prime} 07^{\prime \prime} \mathrm{N}, 125^{\circ} 07^{\prime} 25^{\prime \prime} \mathrm{W}\right)$, Wizard Islet $\left(48^{\circ} 51^{\prime} 27^{\prime \prime} \mathrm{N}, 125^{\circ} 09^{\prime} 38^{\prime \prime} \mathrm{W}\right)$, Kirby Point $\left(48^{\circ} 50^{\prime} 49^{\prime \prime} \mathrm{N}, 125^{\circ} 12^{\prime} 28^{\prime \prime} \mathrm{W}\right)$, Scott's Bay $\left(48^{\circ} 50^{\prime} 13^{\prime \prime} \mathrm{N}\right.$, $125^{\circ} 08^{\prime} 40^{\prime \prime} \mathrm{W}$, Voss Point ( $48^{\circ} 49^{\prime} 47^{\prime \prime} \mathrm{N}, 125^{\circ} 11^{\prime} 26^{\prime \prime} \mathrm{W}$ ),
Prasiola Point $\left(48^{\circ} 49^{\prime} 03^{\prime \prime} \mathrm{N}, 125^{\circ} 10^{\prime} 10^{\prime \prime} \mathrm{W}\right)$, Cape Beale $\left(48^{\circ} 47^{\prime} 02^{\prime \prime} \mathrm{N}, 125^{\circ} 12^{\prime} 57^{\prime \prime} \mathrm{W}\right.$ and Folger Island $\left(48^{\circ} 49^{\prime} 45^{\prime \prime} \mathrm{N}, 125^{\circ} 15^{\prime} 06^{\prime \prime} \mathrm{W}\right)$ (Fig. 1). These 10 sites were selected to cover a broad gradient of exposure to wave action, from very sheltered to fully exposed to open ocean surge and waves. We referred to Rawlings $(1994,1995)$ for the ranking of 8 of these sites with regards to level of wave exposure; Rawlings ranked the sites based on the maximum height of the Balanus glandula zone and the lowest height of vascular plants. We ranked the 2 remaining sites (Dixon Island sheltered and Scott's Bay) relative to the other 8 sites based on our observations of the zonation of $B$. glandula and vascular plants as well as our observations of wave action at the 10 sites. Based on the above information the 10 sites were grouped into 4 categories of wave exposure: full exposure to the open ocean (full exposure), partial shelter from open ocean swell (high exposure), intermediate shelter from open ocean swell (moderate exposure), and extensive shelter from open ocean swell (low exposure). The sites were also selected as being distant from each other by at least $500 \mathrm{~m}$, and all sites except the 2 Dixon Island sites are isolated from other sites

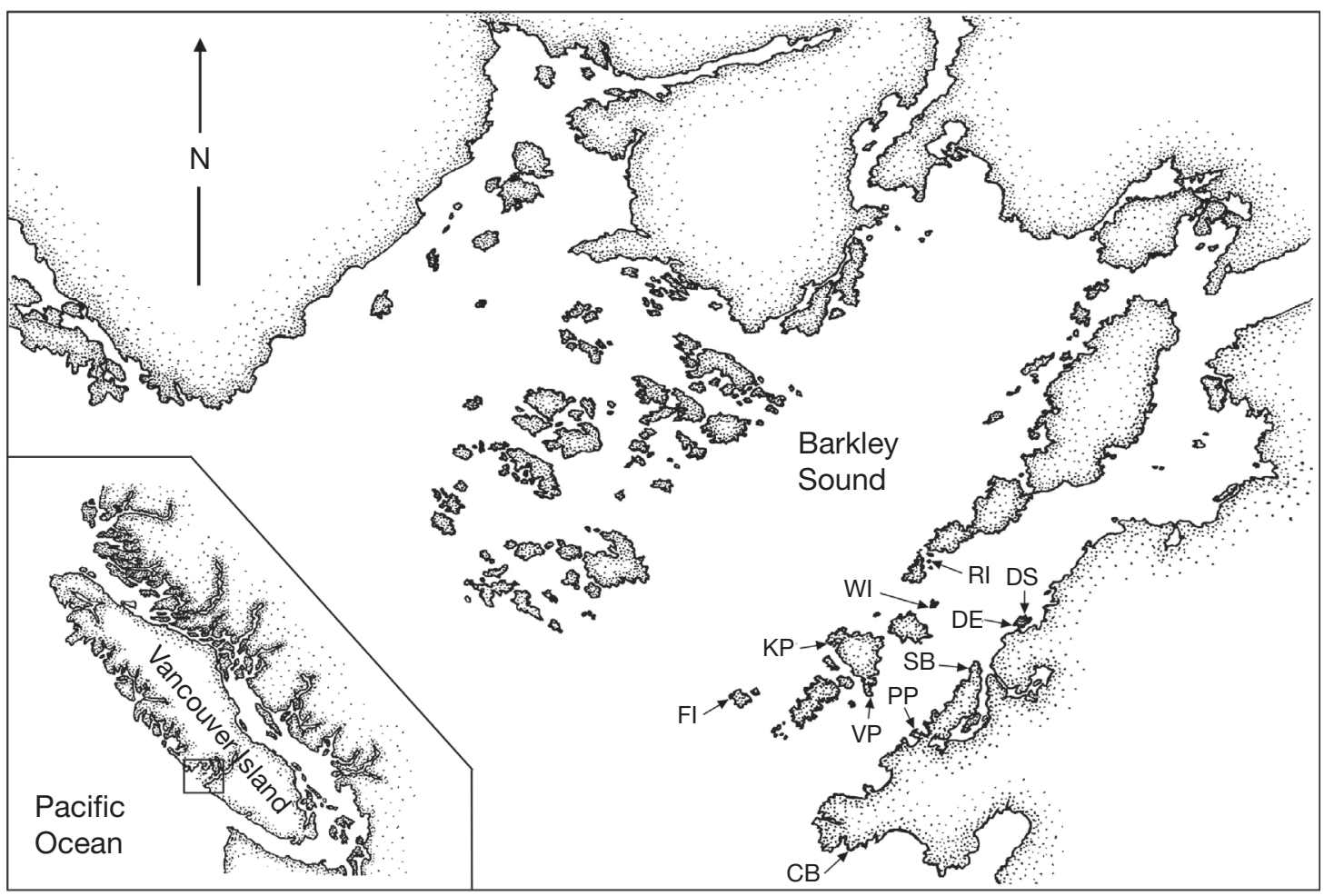

Fig. 1. Barkley Sound: location of 10 Nucella ostrina populations examined in this study (modified from Gosselin \& Chia 1995b). The 2 most distant sites, Ross Islets and Cape Beale, are $10.4 \mathrm{~km}$ apart; the 2 closest sites, Dixon Island exposed and Dixon Island sheltered, are $500 \mathrm{~m}$ apart. CB, Cape Beale; DE, Dixon Island exposed; DS, Dixon Island sheltered; FI, Folger Island; KP, Kirby Point; PP, Prasiola Point; RI, Ross Islets; SB, Scott's Bay; VP, Voss Point; WI, Wizard Islet 
by open water or by stretches of soft-sediment (sand or mud) intertidal areas that act as barriers to dispersal of $N$. ostrina. The 2 most distant sites, Ross Islets and Cape Beale, were $10.4 \mathrm{~km}$ apart; the 2 closest sites, Dixon Island exposed and Dixon Island sheltered, were $500 \mathrm{~m}$ apart.

Hatching size measurements. To quantify variation in hatching size among Nucella ostrina populations, ripe egg capsules (i.e. containing fully developed hatchlings and in which the plug had recently dissolved) were collected from each of the 10 field sites. Only the first 5 of the sites listed above were sampled in 1999; all 10 sites were sampled in 2000 and again in 2001. No more than 2 capsules were collected from any given clutch, in order to distribute sampling effort among females in the population. At least 30 capsules were collected from each site on a given year, except for Folger Island in 2001 (4 capsules ) and Kirby Point in 1999 ( 20 capsules) due to few ripe capsules being found. Ripe capsules were returned to the laboratory and placed in cages in flowing seawater to allow snails to hatch. The shell length of each hatchling, from the tip of the apex to the front tip of the aperture, was measured under a dissecting microscope to an accuracy of $0.02 \mathrm{~mm}$ within $72 \mathrm{~h}$ of emerging from the egg capsule. These hatchlings were not provided with food; therefore, growth during the brief interval between hatching and measurement would have been insignificant (Gosselin \& Chia 1994). Finally, shell length measurements were also converted to estimates of total organic carbon per hatchling using a regression equation for hatchling $N$. ostrina reported by Moran \& Emlet (2001).

Hatchling predator feeding preferences. Gosselin \& Chia (1995b) reported that the hermit crabs Pagurus hirsutiusculus and P. granosimanus and the shore crab Hemigrapsus nudus were the main predators of early juvenile Nucella ostrina. This conclusion was based on abundances in the field and on laboratory experiments in which hatchlings were offered to 45 species of potential predators. However, that study did not examine whether these predators preferred $N$. ostrina hatchlings relative to other food types available in the field. To determine if hatchlings are a preferred food item of these crab species, and therefore to verify whether these crabs actually constitute a threat to hatchlings in the field, we examined the feeding preferences of the 3 predators. Predators were collected at the Ross site $1 \mathrm{~d}$ prior to beginning each of the following feeding trials.

Potential food items: These trials were aimed at determining which items the hermit crabs might use as food. Twenty individuals of each Pagurus species (10 small individuals: 3.1 to $4.9 \mathrm{~mm}$ claw length [CL]; 10 large individuals: 5.5 to $8.5 \mathrm{~mm} \mathrm{CL}$ ) and 15 small Hemigrapsus nudus (5.2 to $7.7 \mathrm{~mm} \mathrm{CL}$ ) were used. These crab sizes were selected based on the sizes most commonly found in the field. The crabs were placed in individual cages (95 $\times 95 \times 60 \mathrm{~mm}$, with $610 \mu \mathrm{m}$ mesh) and left undisturbed to acclimatise for $2 \mathrm{~h}$, after which either Nucella ostrina hatchlings, $N$. ostrina egg capsules containing developing embryos, or 1 of 6 other organisms found in the same intertidal habitats as $N$. ostrina was added to the cage as a potential food item, as listed in Table 1. All replicate cages simultaneously received the same food item. After adding 1 item to each cage, all cages were placed in an outdoor seawater tank with flowing seawater for $10 \mathrm{~h}$. The crabs were then moved to new cages for $2 \mathrm{~h}$ before being offered the next food item, while all potential food items in the first set of cages were examined using a dissecting scope to determine if they had been preyed upon by the crabs.

Preferred food items: After determining which items the predators were willing to consume, food preference trials were carried out using new sets of predators. Given the low abundance of Pagurus granosimanus in habitats where Nucella ostrina hatchlings were found, the prey preferences of this predator were not examined. Pagurus hirsutiusculus sample sizes consisted of 25 small ( $\leq 5.5 \mathrm{~mm} \mathrm{CL}$ ) and 21 large ( $\geq 5.6 \mathrm{~mm} \mathrm{CL}$ ) crabs. An initial experiment with Hemigrapsus nudus, in which Ulva sp. was offered as 1 of the food items, included 21 crabs (5.5 to $8.1 \mathrm{~mm} \mathrm{CL}$ ). A second $H$. nudus experiment, without Ulva sp., included 25 crabs of the same size range as in Expt 1.

Pagurus hirsutiusculus and Hemigrapsus nudus were individually placed in cages as in the potential food item experiment, but were then simultaneously provided with 1 of each of the food items previously consumed by this predator in the first experiment. Each $P$. hirsutiusculus was offered 1 Lasaea sp., $1 \mathrm{Nu}$ cella ostrina hatchling, and 1 small Mytilus spp. within the size ranges listed in Table 1 . In the first $H$. nudus experiment, each crab was offered 1 section $\left(1.5 \mathrm{~cm}^{2}\right)$

Table 1. Organisms offered to crabs as potential food items

\begin{tabular}{|lll|}
\hline \multirow{2}{*}{ Food item } & Species & Size included in experiment \\
\hline \multirow{2}{*}{ Algae } & Fucus gardneri & $1.5 \mathrm{~cm}^{2}$ section \\
& Ulva sp. & $1.5 \mathrm{~cm}^{2}$ section \\
Bivalves & Mytilus spp. & $1.4-3.8 \mathrm{~mm}$ shell length \\
& Lasaea sp. & $1.35-3.05 \mathrm{~mm}$ shell length \\
Gastropods & Littorina scutulata & $0.93-1.55 \mathrm{~mm}$ shell length \\
& Nucella ostrina hatchlings & $0.85-2.03 \mathrm{~mm}$ shell length \\
& N. ostrina egg capsules & $0.7 \mathrm{~mm}$ height \\
Crustacean & Dynamenella sheareri & $3.2-3.5 \mathrm{~mm}$ \\
& & \\
\hline
\end{tabular}


of Ulva sp., 1 section of Fucus gardneri, 1 Mytilus spp. and $1 \mathrm{~N}$. ostrina hatchling. In the second $H$. nudus experiment, the same food items were provided with the exception of Ulva sp. All cages were inspected after 30,60 , and $120 \mathrm{~min}$, and then every $2 \mathrm{~h}$ up to a total duration of $8 \mathrm{~h}$ to identify the first food item attacked by each predator. Cases in which either no food was consumed or more than 1 item was consumed, i.e. in which it was impossible to identify the first prey item, were not used in our analyses of food preferences.

Predator population size-structure and predation susceptibility index. To determine how susceptibility to predators in the field changes as a function of hatching size, we determined the predation susceptibility index (Gosselin 1997) for Nucella ostrina hatchlings at 4 sites. The predation susceptibility index represents the total density (ind. $\mathrm{m}^{-2}$ ) of predators at a given field site that would prey on a snail of a given size. To determine the predation susceptibility index, we assessed the abundance and size structure of each species of hermit crabs (Pagurus hirsutiusculus, P. granosimanus and P. samuelis) and shore crabs (Hemigrapsus nudus and $H$. oregonensis) at each of the 4 sites. We then calculated the index based on our data of the abundance and size structure of each predator population for each of the 4 sites, and the known size range of each predator species capable of killing hatchlings of the given size as determined by Gosselin (1997). This calculation was repeated for the full range of $N$. ostrina hatching sizes to obtain a relationship between predator susceptibility and hatching size. The index values calculated herein assume that hermit crabs and shore crabs will feed on $N$. ostrina hatchlings in the field as they did in

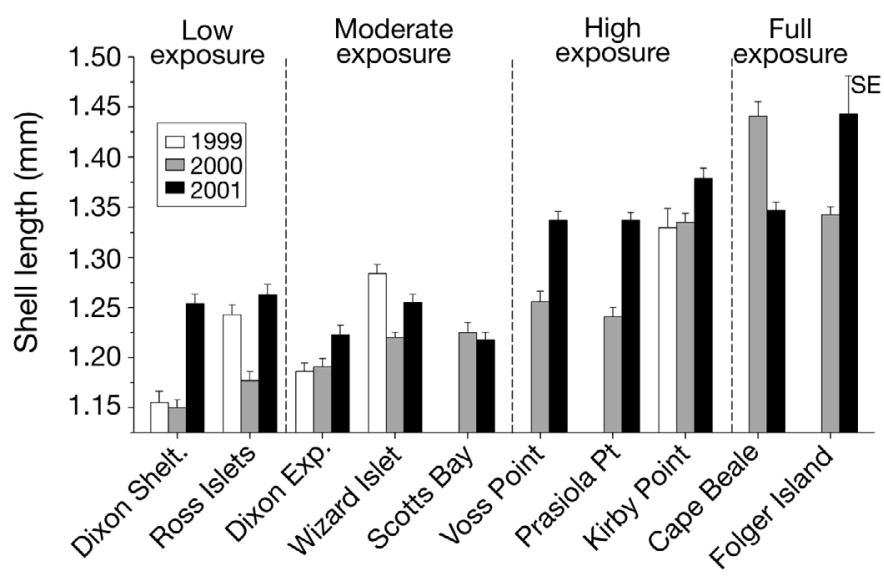

Fig. 2. Nucella ostrina. Average size at hatching of 10 populations in Barkley Sound, British Columbia, in 1999, 2000 and 2001. Dashed vertical lines divide the sites into 4 groups according to exposure to wave action, from low exposure to wave action to full exposure the laboratory, and that virtually all early juvenile snail mortality to predators is caused by hermit crabs and shore crabs, which is likely the case (Gosselin \& Chia 1995b, Gosselin 1997).

Predator populations were sampled at the Ross Islets, Dixon Island exposed, Wizard Islet and Scott's Bay sites between 17 July and 5 August 2000, a period during which many hatchlings were emerging from egg capsules at these sites. The sampling procedure was similar to that used by Gosselin (1997); briefly, three $5 \mathrm{~m}$ horizontal transects were positioned parallel to the shore at each site. On each transect line, five $25 \times 25 \mathrm{~cm}$ quadrats were positioned at $1 \mathrm{~m}$ intervals, resulting in a total of 15 quadrats per site. All crabs within these quadrats were collected and returned to the laboratory. The length of the right claw of each crab was measured unless that claw was missing or visibly smaller than the left claw, in which case the left claw was measured. To determine if the relationship between predator susceptibility and hatching size is consistent over time at a given site, we compared our results from 2000 with the results of a similar study by Gosselin (1997) carried out at 3 of these 4 sites (Ross, Dixon Island exposed, and Wizard) in 1993.

\section{RESULTS}

\section{Variation in hatching size}

Hatching sizes were compared using a 2-factor ANOVA with site (10 field sites) and year (2000 and 2001) as independent variables; measurements from 1999, the first year of the study, were not included in this analysis as only 5 of the 10 sites were surveyed that year. Hatching size was found to differ significantly among sites (Fig. 2, Table 2). However, a significant interaction between sites and years (Table 2) revealed that the trend in average hatching size among populations was not identical from year to year. This is apparent, for example, in the Dixon Island shel-

Table 2. Nucella ostrina. Results of ANOVA comparing hatching size among 10 populations and years, with Population and Year being fixed factors. Analysis included hatching sizes from 2000 and 2001 only

\begin{tabular}{|lrrrrr|}
\hline Source & Type III SS & df & MS & \multicolumn{1}{c|}{$F$} & $\mathrm{p}$ \\
\hline Model & 14425.21 & 20 & 721.26 & 21046.73 & $<0.001$ \\
Population & 29.31 & 9 & 3.26 & 95.03 & $<0.001$ \\
Year & 2.19 & 1 & 2.19 & 63.95 & $<0.001$ \\
Population vs. Year & 5.74 & 9 & 0.64 & 18.6 & $<0.001$ \\
Error & 307.23 & 8965 & 0.034 & & \\
\hline
\end{tabular}


Table 3. Nucella ostrina. Range of average population hatching sizes for each year of the study. Estimates of organic carbon content calculated using the regression equation for newly hatched $N$. ostrina: $\log _{10}(\mu \mathrm{g}$ organic content $)=1.69 \times$ shell length - 0.39 (Moran \& Emlet 2001). Note that values for 1999 are based on the study of 5 populations; values for 2000 and 2001 report the range among all 10 populations

\begin{tabular}{|lcc|}
\hline & $\begin{array}{c}\text { Average } \\
\text { shell } \\
\text { length (mm) }\end{array}$ & $\begin{array}{c}\text { Estimated avg. } \\
\text { organic carbon } \\
\text { content }(\mu \mathrm{g})\end{array}$ \\
\hline $\mathbf{1 9 9 9}$ & & \\
$\begin{array}{l}\text { Smallest: Dixon Island sheltered } \\
\text { Largest: Kirby }\end{array}$ & 1.16 & 36.5 \\
\% difference & 1.33 & 72.0 \\
$\mathbf{2 0 0 0}$ & 15.1 & 97.2 \\
Smallest: Dixon Island sheltered & 1.15 & \\
Largest: Cape Beale & 1.44 & 111.0 \\
\% difference & 25.3 & 210.3 \\
$\mathbf{2 0 0 1}$ & & \\
Smallest: Scott's Bay & 1.22 & 46.6 \\
Largest: Folger & 1.44 & 111.9 \\
\% difference & 18.5 & 140.0 \\
\hline
\end{tabular}

Table 4. Nucella ostrina. Intrapopulation variation in hatching size among 10 populations in Barkley Sound, British Columbia, Canada

\begin{tabular}{|c|c|c|c|c|}
\hline Population & Year & $\mathrm{N}$ & $\begin{array}{c}\text { Range of } \\
\text { hatching sizes } \\
\text { (mm shell length) }\end{array}$ & $\begin{array}{c}\text { Coefficient } \\
\text { of variation } \\
(\%)\end{array}$ \\
\hline $\begin{array}{l}\text { Dixon Island, } \\
\text { sheltered }\end{array}$ & $\begin{array}{l}1999 \\
2000 \\
2001\end{array}$ & $\begin{array}{l}203 \\
487 \\
444\end{array}$ & $\begin{array}{l}0.76-1.78 \\
0.70-1.68 \\
0.79-2.00\end{array}$ & $\begin{array}{l}13.5 \\
15.2 \\
14.7\end{array}$ \\
\hline Ross & $\begin{array}{l}1999 \\
2000 \\
2001\end{array}$ & $\begin{array}{l}300 \\
412 \\
355\end{array}$ & $\begin{array}{l}0.78-1.63 \\
0.75-1.88 \\
0.75-1.85\end{array}$ & $\begin{array}{l}13.7 \\
16.0 \\
14.9\end{array}$ \\
\hline Wizard & $\begin{array}{l}1999 \\
2000 \\
2001\end{array}$ & $\begin{array}{l}442 \\
947 \\
481\end{array}$ & $\begin{array}{l}0.70-1.95 \\
0.70-1.70 \\
0.68-1.85\end{array}$ & $\begin{array}{l}14.3 \\
13.5 \\
14.6\end{array}$ \\
\hline $\begin{array}{l}\text { Dixon Island, } \\
\text { exposed }\end{array}$ & $\begin{array}{l}1999 \\
2000 \\
2001\end{array}$ & $\begin{array}{l}582 \\
454 \\
423\end{array}$ & $\begin{array}{l}0.70-1.71 \\
0.68-1.80 \\
0.75-1.80\end{array}$ & $\begin{array}{l}15.3 \\
15.0 \\
15.8\end{array}$ \\
\hline Scott's Bay & $\begin{array}{l}2000 \\
2001\end{array}$ & $\begin{array}{l}456 \\
622\end{array}$ & $\begin{array}{l}0.68-1.88 \\
0.77-1.80\end{array}$ & $\begin{array}{l}17.0 \\
13.5\end{array}$ \\
\hline Voss & $\begin{array}{l}2000 \\
2001\end{array}$ & $\begin{array}{l}364 \\
413\end{array}$ & $\begin{array}{l}0.78-1.70 \\
0.73-1.85\end{array}$ & $\begin{array}{l}15.9 \\
14.0\end{array}$ \\
\hline Prasiola & $\begin{array}{l}2000 \\
2001\end{array}$ & $\begin{array}{l}484 \\
392\end{array}$ & $\begin{array}{l}0.65-1.88 \\
0.73-1.91\end{array}$ & $\begin{array}{l}15.5 \\
12.0\end{array}$ \\
\hline Kirby & $\begin{array}{l}1999 \\
2000 \\
2001\end{array}$ & $\begin{array}{l}103 \\
639 \\
226\end{array}$ & $\begin{array}{l}0.95-1.93 \\
0.73-2.08 \\
1.01-1.83\end{array}$ & $\begin{array}{l}14.4 \\
16.1 \\
11.2\end{array}$ \\
\hline Cape Beale & $\begin{array}{l}2000 \\
2001\end{array}$ & $\begin{array}{l}215 \\
561\end{array}$ & $\begin{array}{l}0.85-2.25 \\
0.77-1.96\end{array}$ & $\begin{array}{l}14.7 \\
14.2\end{array}$ \\
\hline Folger & $\begin{array}{l}2000 \\
2001\end{array}$ & $\begin{array}{r}593 \\
17\end{array}$ & $\begin{array}{l}0.78-1.95 \\
1.06-1.65\end{array}$ & $\begin{array}{l}13.4 \\
11.1\end{array}$ \\
\hline
\end{tabular}

tered population, which had the smallest average hatching size in 2000 but the third smallest in 2001 (Fig. 2). Despite this year-to-year variation, populations were quite consistent in producing average hatching sizes that were small, intermediate, or large. A Spearman rank-order correlation analysis between average hatching size and wave exposure, where all sites within an exposure category were given the same rank, revealed a strong correlation for $2000\left(\mathrm{r}_{\mathrm{S}}=0.969\right.$, $\mathrm{n}=10, \mathrm{p}<0.001)$ and $2001\left(\mathrm{r}_{\mathrm{S}}=0.784, \mathrm{n}=10, \mathrm{p}=\right.$ $0.007)$ : average population hatching size increased with wave exposure. The correlation was not significant for $1999\left(\mathrm{r}_{\mathrm{S}}=0.738, \mathrm{n}=5, \mathrm{p}=0.155\right)$ due to the small number of replicates and because only 1 site with high exposure and no site with full exposure was sampled that year.

The range in average population hatching sizes among these 10 populations was considerable. The largest average hatching shell length was 15 to $25 \%$ longer than the smallest average shell length (Table 3). When shell lengths were converted to estimates of average total organic content using a regression equation for hatchling Nucella ostrina (Moran \& Emlet 2001, Regression Eq. D: $\log _{10}(\mu \mathrm{g}$ organic carbon content) $=1.69 \times$ shell length -0.39 ), the greatest average organic content among these 10 populations was 140 to $210 \%$ higher than the smallest average organic content (years 2000 and 2001, Table 3).

Over the 3 years of this study, 10561 hatchlings were measured; of the 25 sets of hatchlings that were obtained (5 populations in 1999 and 10 populations in 2000 and 2001), 23 consisted of more than 200 hatchlings (Table 4). Although the populations differed in average hatching size, there was little difference among populations in the range of sizes produced. All populations produced at least a few hatchlings smaller than $0.8 \mathrm{~mm}$ shell length, and even the populations with the smallest average sizes produced some hatchlings larger than $1.8 \mathrm{~mm}$ (Table 4). Coefficients of variation for hatching size in all populations were within the range of 11 to $17 \%$.

\section{Hatchling predator feeding preferences}

Potential food items

When presented with a single food type at a time, all 3 predator species and each hermit crab size class readily consumed Nucella ostrina hatchlings. These predator species also fed on a variety of other food items: Hemigrapsus nudus consumed all food types that were offered, and the 2 hermit crab species readily consumed all food types except egg capsules and Fucus gardneri (Fig. 3). However, hermit crabs in the 


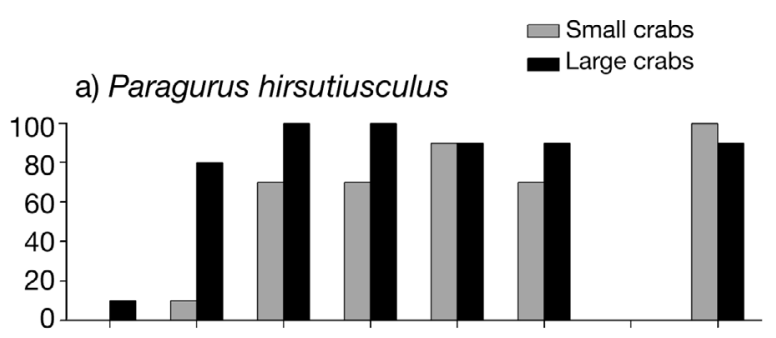

b) Paragurus granosimanus

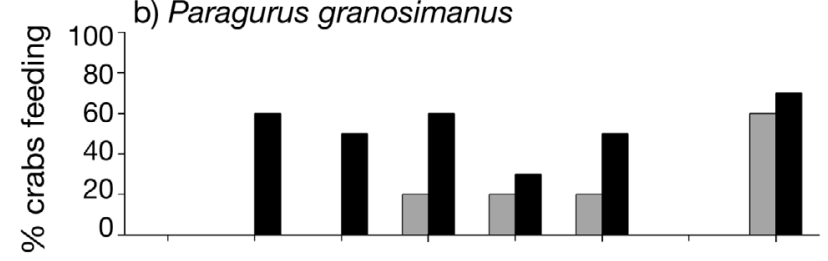

c) Hemigrapsus nudus

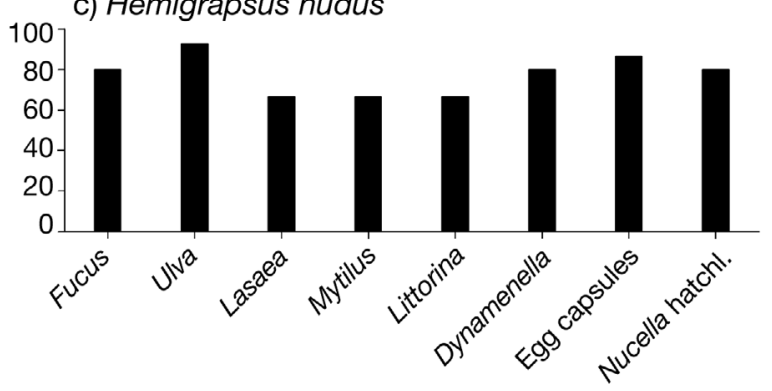

Food item

Fig. 3. (a) Paragurus hirsutiusculus, (b) P. gransimanus and (c) Hemigrapsus nudus. Proportion of crabs that fed on 8 potential food items found in rocky mid-intertidal habitats of Barkley Sound, British Columbia. Plotted values represent proportion of predators consuming the given food item over a $10 \mathrm{~h}$ period when provided with only that food type

smaller size class - most noticeably Pagurus granosimanus-consumed fewer food types than the larger hermit crabs. Hemigrapsus nudus appears to have the broadest diet, as all food types were consumed by $70 \%$ or more of the crabs, including F. gardneri and egg capsules.

\section{Preferred food items}

Nucella ostrina hatchlings were found to be a favoured food item of most predators. When simultaneously provided with a range of food types known to be abundant in the field and acceptable to the predators, most predators did not attack prey randomly (Fig. 4). An analysis of the first food item consumed by these predators reveals that attack frequencies by small Pagurus hirsutiusculus were significantly different from expected frequencies based on an even distribution of attacks among prey species (Goodness-of-fit test: $G_{\text {adj }}=10.981, \mathrm{p}<0.005, \mathrm{df}=2 ; G$-value adjusted using Williams' correction, Sokal \& Rohlf 1981). The first item to be consumed by most small $P$. hirsutiusculus was a $N$. ostrina hatchling (Fig. 4a). The pattern was similar for large $P$. hirsutiusculus, but the attack frequencies of the prey types were not significantly different from an even distribution (Goodness-of-fit test: $G_{\mathrm{adj}}=1.861, \mathrm{p}>0.3, \mathrm{df}=2$ ). Attack frequencies by Hemigrapsus nudus were significantly different from an even distribution of attacks among prey species, both in the presence of Ulva sp. (Goodness-of-fit test: $G_{\text {adj }}=48.269, \mathrm{p}<0.005, \mathrm{df}=3$ ) and in a second trial without Ulva sp. (Goodness-of-fit test: $G_{\mathrm{adj}}=9.941, \mathrm{p}<$ 0.01 , df $=2$ ). When Ulva sp. was included as a food type, this algae was strongly preferred over other food types, with $95 \%$ of the crabs feeding on Ulva sp. (Fig. 4b). In the absence of Ulva sp., Mytilus spp. was the most frequently attacked food type, followed by $N$. ostrina hatchlings (Fig. 4c).
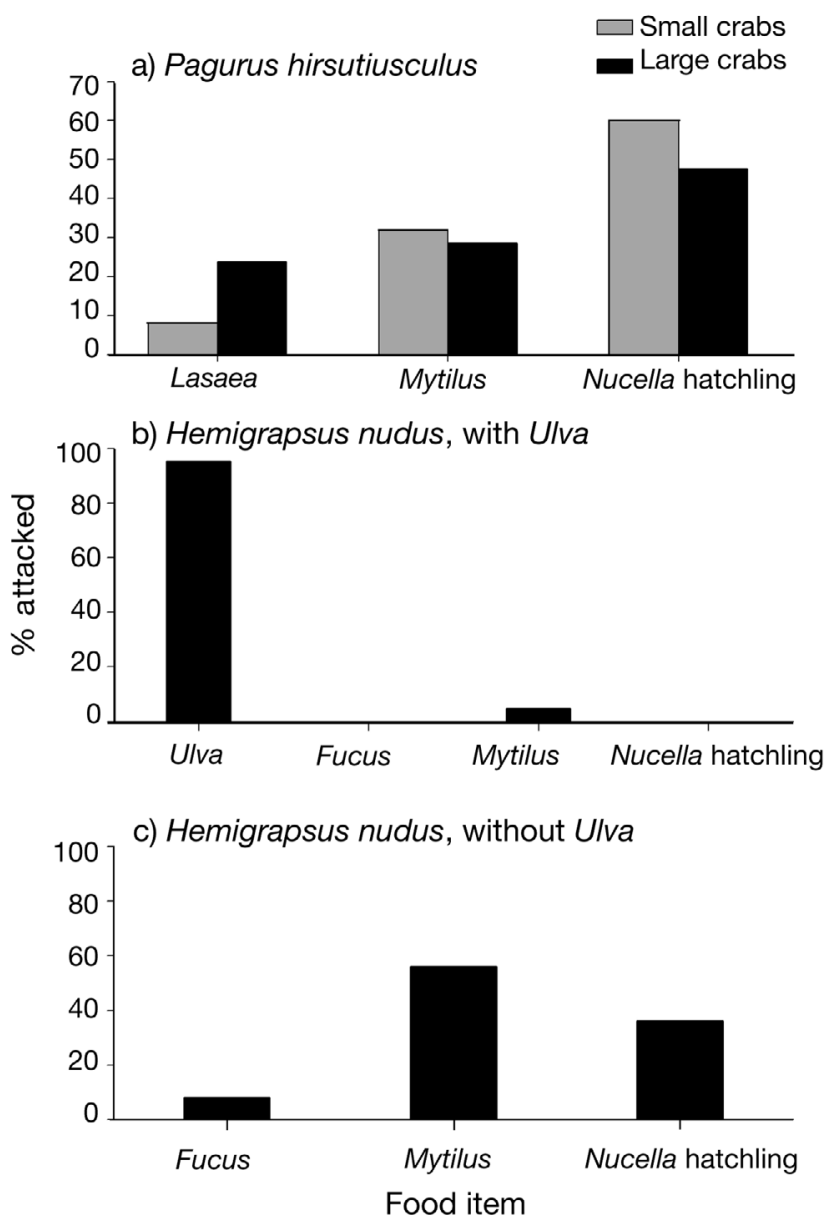

Fig. 4. (a) Pagurus hirsutiusculus, and $(\mathrm{b}, \mathrm{c})$ Hemigrapsus nudus with and without Ulva sp. Prey preferences of $2 \mathrm{crab}$ species. Each individual predator was offered 1 item of each food type common in the field and shown to be acceptable to them as food. The first item consumed by each crab was recorded. Plotted values represent the proportion of crabs that preyed on the given food item on their first attack 


\section{Predator population size-structure and predation susceptibility index}

At the 4 field sites where hatchling predator populations were examined, Pagurus hirsutiusculus was the most abundant predator, with a predominance of small individuals (Fig. 5). Hemigrapsus nudus was present at all sites, but in relatively low densities. Few P. granosi-

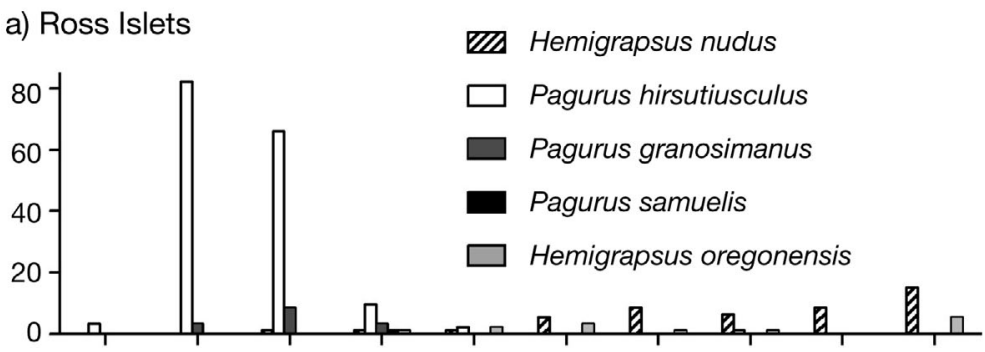

b) Wizard Islet

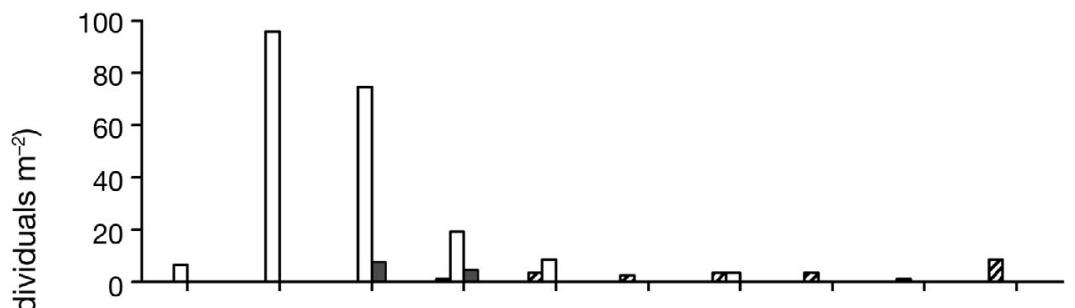

c) Dixon Island, exposed

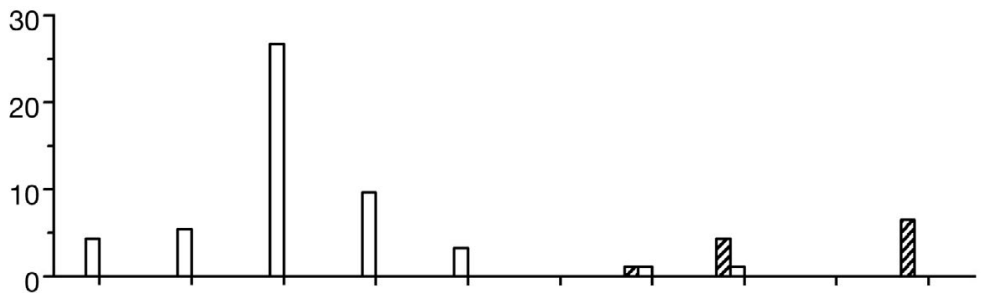

d) Scott's Bay

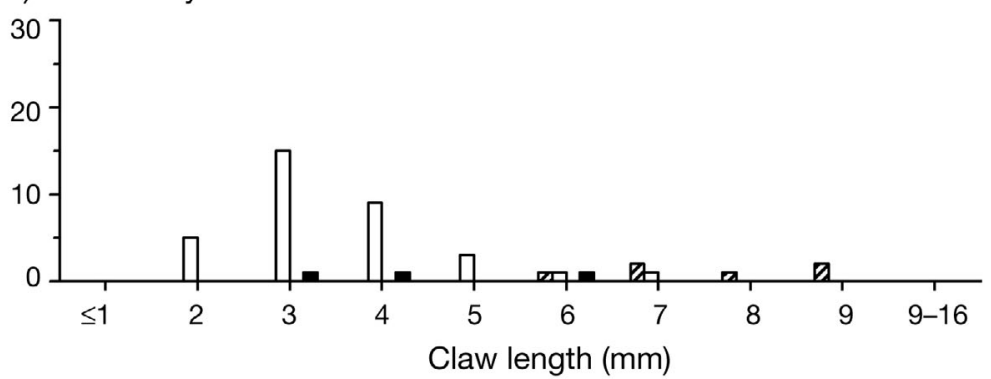

Fig. 5. Hemigrapsus spp. and Pagurus spp. Size-frequency distribution of hatchling predators at 4 field sites in July and August 2000. Measurements were generally taken on the crab's right claw. Each unit of the $x$-axis (claw length) represents the $1 \mathrm{~mm}$ interval preceding the listed value (e.g. 1.1-2.0 mm listed as $2 \mathrm{~mm}$ ) manus and $P$. samuelis were found in the quadrats at any of the 4 sites, and were not found at Dixon Island exposed.

The above values were used to calculate the predation susceptibility index, which is the sum of the densities (ind. $\mathrm{m}^{-2}$ ) of all predators able to prey on snails of a given size. Index values revealed that snail sizes within the range at which most Nucella ostrina hatch ( 0.7 to $2 \mathrm{~mm}$ shell length [SL]) would be particularly susceptible to predation (Fig. 6). Within that size range, however, susceptibility to predators decreased much more rapidly at the Ross and Wizard sites than at the Dixon Island exposed and Scott's Bay sites. This is primarily because a large hatchling cannot be consumed by the smallest predators, and is therefore vulnerable to fewer small predators than a smaller hatching size, and because the predator populations at the Ross and Wizard sites included a much higher proportion of small predators than the Dixon Island exposed and Scott's Bay sites. Although the abundance of predators was lower in 2000 than measured by Gosselin (1997) in 1993, the pattern of susceptibility to predation as a function of snail size at each site was the same for each of those years. In addition, the same pattern is apparent whether or not Hemigrapsus nudus is included in the index calculations.

Average hatching size of Nucella ostrina at these 4 sites did not consistently match the pattern of susceptibility to predation. Hatching sizes did differ significantly among these 4 populations (2 factor ANOVA, with site and year as independent variables: $\mathrm{n}=5420, F=$ 21.437, p < 0.001). However, there was a significant interaction between site and year $(F=10.606, \mathrm{p}<0.001)$, with the relative ranking of the sites changing from one year to the next (Fig. 7). When sites were compared separately for each year using Tukey's Honestly Significant Difference (HSD) multiple comparisons tests (Fig. 7), the Ross and Wizard sites had significantly larger average hatching sizes than Dixon Island exposed and Scott's Bay in 1999 and 2001, but not in 2000. In fact, Ross had the smallest hatching size in 2000, while Scott's Bay had the largest hatchlings. 
a) 1993

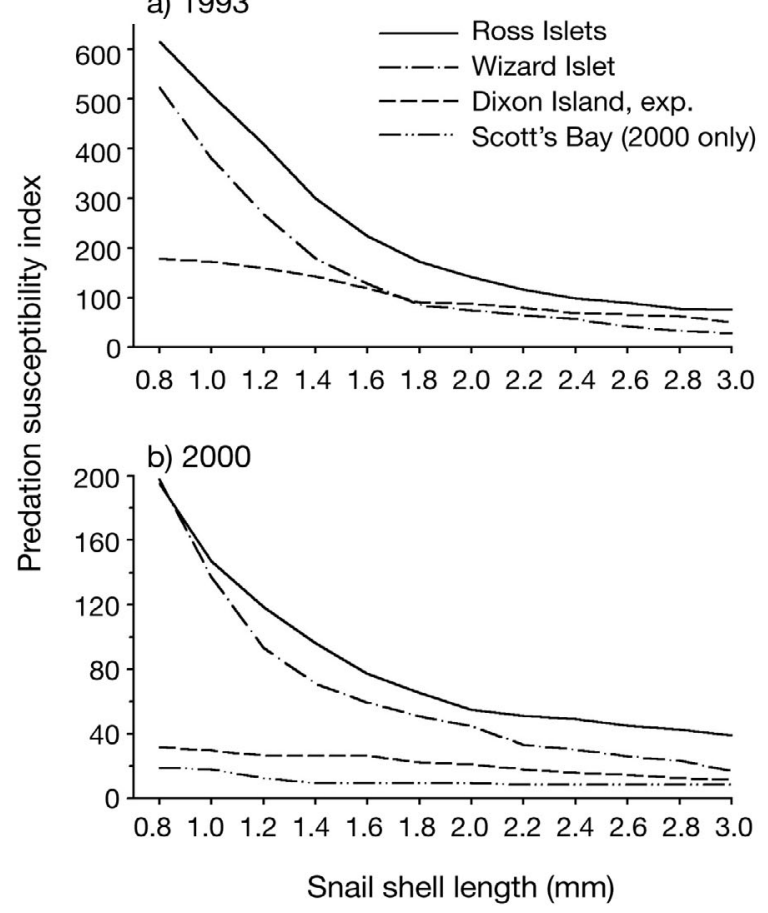

c) 1993, without Hemigrapsus spp.

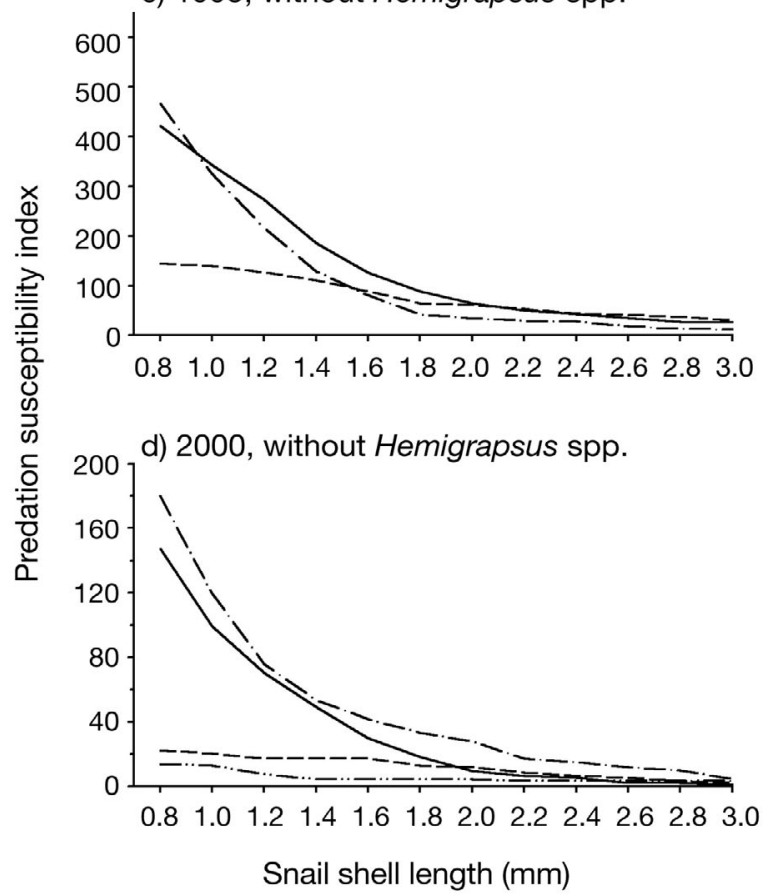

Fig. 6. Nucella ostrina. Susceptibility of early juveniles to hatchling predators as a function of shell length. Predation susceptibility index consists of the density (ind. $\mathrm{m}^{-2}$ ) of all hatchling predators that would kill a snail of a given size. Data for 1993 (a,c) modified from Gosselin (1997)

\section{DISCUSSION}

\section{Variation in hatching size}

Hatching size differed substantially among the 10 populations of Nucella ostrina in Barkley Sound. Average hatching shell length differed among populations by as much as $25 \%$ in a given year. Average estimated organic content, a currency that expresses initial juvenile size in units indicative of energy reserves of the newly hatched snail and of maternal investment per offspring, differed by up to $210 \%$ among the 10 populations. These are considerable differences given the proximity of these populations, the most distant populations being only $10 \mathrm{~km}$ apart. These differences were broadly consistent over the 3 years of the study, some populations consistently producing larger average hatching sizes than other populations. Therefore, the 10 populations produce offspring that differ considerably not only in size but also in the amount of energy reserves held at the start of juvenile life.

In addition to interpopulation variation in size at hatching, substantial variation was also found within each Nucella ostrina population in any given year, and among years for most populations. All populations produced at least a few very small $(<0.8 \mathrm{~mm} \mathrm{SL})$ and large
(>1.8 $\mathrm{mm}$ SL) hatchlings, with the largest hatchling always being 2 to 3 times larger in shell length than the smallest. The smallest hatchlings were consistently very close to $0.7 \mathrm{~mm} \mathrm{SL}$, which may be the lower limit of hatching size in this species.

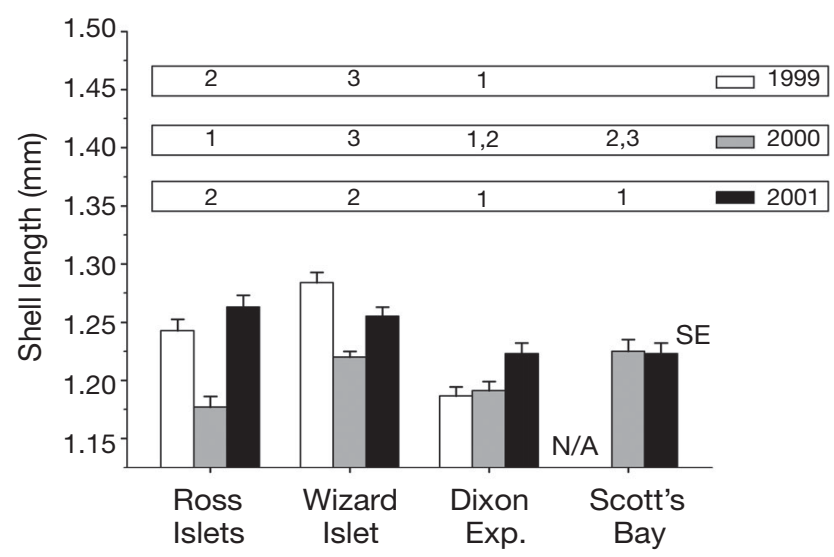

Fig. 7. Nucella ostrina. Average hatching size of 4 populations for which the predation susceptibility index was determined. For each year of the study, populations were ranked according to average hatching size: numbers above bars indicate the ranking for a given year, from smallest to largest average shell length based on Tukey's HSD multiple comparisons test (Zar 1999). Average shell lengths that do not differ significantly are ranked with the same number 


\section{Influence of predation pressure on hatching size}

Predation by shell-crushing crustaceans has influenced the evolution of shell morphology of marine snails (Vermeij 1978, Palmer 1985, Boulding 1990). Predation pressure might therefore also be expected to influence the size at which marine snails begin early juvenile life, as suggested by Spight (1976a).

Our feeding trials do indicate that hatchlings are highly favoured as a food source by hermit crabs, especially by small hermit crabs, and are moderately favoured by shore crabs, suggesting that most of these predators would readily consume hatchlings in the field if encountered. Of the 4 sites where predator populations were studied in 2000, susceptibility of hatchlings to predation at 2 sites-Ross and Wizard-decreased rapidly with increasing snail size over the range of sizes at which Nucella ostrina hatch. At these 2 sites, an increase in the size at which snails emerge from their egg capsules would therefore result in a greater reduction in susceptibility to predation than at the Dixon Island exposed and Scott's Bay sites, where susceptibility to predation changed very little over that same range of snail hatching sizes. These trends, documented in 2000, were the same as observed $7 \mathrm{yr}$ earlier at 3 of these sites by Gosselin (1997). The consistency of the findings in 1993 and 2000 supports the hypothesis that differences in the population structure of hatchling predators among sites are a persistent feature of the environment. If relative levels of predation pressure among sites have indeed persisted over evolutionary time, and predation by these species is an important selective pressure on $N$. ostrina hatching size, then the Ross and Wizard populations would be expected to produce larger hatchlings than the Dixon Island exposed and Scott's Bay populations.

However, in the present study, differences in average hatching size among these 4 populations were modest and not consistently ranked as predicted above. Differences in average hatching size among these 4 populations were $\leq 0.1 \mathrm{~mm}$, compared with the 0.23 (2001) to $0.29 \mathrm{~mm}$ (2000) range in average shell length observed among the 10 populations examined in this study. The Ross and Wizard populations produced slightly larger average hatching sizes than the Dixon Island exposed and Scott's Bay populations in 1999 and 2001, but in 2000 the pattern was reversed, Ross having the smallest average hatching size and Scott's Bay the largest, the opposite of what was predicted based on the predation susceptibility index.

Another line of evidence also suggests that predation is not a major determinant of hatching size in Nucella ostrina. On rocky shores, predator abundance and activity, and corresponding impacts on prey populations, is generally more restricted on shores exposed to intense wave action than on shores with moderate or low wave exposure (Menge 1983, Leigh et al. 1987, Etter 1989, 1996, Boulding \& Van Alstyne 1993, Boulding et al. 1999, Robles et al. 2001). For instance, Hemigrapsus sp. are less abundant at exposed sites than at protected sites in the Tatoosh Island archipelago, Washington, USA (Boulding \& Van Alstyne 1993). These findings are consistent with our personal observations of rocky shores in Barkley Sound over the last 15 years: Pagurus spp. and Hemigrapsus spp. were infrequently observed at the most wave-exposed sites and more commonly observed on moderately exposed or protected shores (authors' pers. obs.). Restricted predator activity at the most wave-exposed sites would be expected to have resulted in smaller average hatching sizes at the most wave-exposed sites than at less exposed sites, the opposite of what we observed among the 10 populations in Barkley Sound. It therefore appears that if predation does influence hatching size in N. ostrina, the effect is modest relative to other factors. This is a surprising finding, as it suggests predation may be less important as a selective pressure on early juveniles than is currently thought (see review by Gosselin \& Qian 1997).

Why is average hatching size not consistent with our data on predation pressure? One possible explanation is that, despite the consistency in predator population structure between the 1993 and 2000 surveys, predator population structure may in fact have changed over evolutionary time at any given site, such that recent predation pressure might be a poor indicator of longterm predation pressure. Also, predation pressure may not have been sufficiently consistent over evolutionary time to cause directional selection in hatching size. Another possible explanation is that predation pressure has been consistent over time, but that other, as yet unrecognized predators of hatchlings, with distributions differing from those of hermit and shore crabs, constitute a substantially greater selective pressure on hatchlings than hermit crabs and shore crabs, thus confounding our results. This, however, seems unlikely, given that (1) no such other species were detected in a broad survey of hatchling predators (Gosselin \& Chia 1995b), (2) the largest average hatching sizes are found on the most wave-exposed shores where intense wave action would limit the activities of motile predators, and (3) the high abundance of known predators (hermit crabs and shore crabs) on shores with relatively small average hatching sizes. A likely alternative is that interpopulation variation in hatching size is determined primarily by factors other than predation. 


\section{Relationship between hatching size and exposure to wave action}

Various aspects of body size and form of marine snails are influenced by wave action (Kitching 1976, Vermeij 1978, Crothers 1983, Boulding 1990). For example, the shells of adult snails on wave-exposed shores are often thinner, smaller and with a proportionally larger aperture than on protected shores (Crothers 1983, Etter 1989, 1996, Boulding 1990). Such variation in shell morphology in gastropods partly results from environmental plasticity but also includes a heritable component (Boulding \& Hay 1993, Carballo et al. 2001). The correlation between hatching size in Nucella ostrina and wave exposure reported in this study indicates that changes in environmental conditions along a wave exposure gradient influence morphology in this species from the very onset of juvenile life. Wave exposure itself might be responsible for the observed differences in $N$. ostrina hatching size along the gradient, for example if dislodgement by waves or crushing by water-borne debris (Shanks \& Wright 1986) is more likely to kill small hatchlings than large ones. Alternatively, the relationship might be due to other factors that covary with wave exposure, such as availability of food or microhabitats that provide shelter for the hatchlings, or factors that influence the female parent rather than the offspring, such food availability prior to spawning.

Etter (1989) reported that hatching size of Nucella lapillus in New England was greatest on wave-protected shores, in sharp contrast to our findings for $N$. ostrina, yet these 2 gastropod species belong to the same genus, live in similar environments (Kitching 1976) and have a similar mode of reproduction. The 2 studies reveal that there is no universal pattern in the relationship between initial juvenile size and waveexposure. Nevertheless, both studies do support the hypothesis that factors influencing hatching size vary along gradients of wave exposure. Wave action or other factors covarying with wave action would be the primary factors responsible for the observed pattern of average population hatching size in $N$. ostrina.

\section{Environmental severity and offspring size}

If initial juvenile size is determined by environmental severity, then what constitutes a severe environment for an early juvenile? According to Stearns (1992), life history traits are strongly influenced by mortality schedules, and associations between environmental conditions and life-history traits occur through the influence of environmental conditions on the mortality regime. Seemingly conflicting conclusions regarding the relationship between environmental severity and offspring size (e.g. Moran \& Emlet 2001 vs. Marshall \& Keough 2003; Etter 1989 vs. present study) are probably due to our poor understanding of the relative influence of environmental factors on early juvenile mortality and reproductive traits of the female parent, particularly maternal provisioning. Predation has been suggested as an important mortality factor influencing offspring size (Spight 1976a), yet that hypothesis was not well supported by our results for Nucella ostrina. Another factor considered to be a major cause of early juvenile mortality in intertidal invertebrates, including N. ostrina, is desiccation stress (Gosselin \& Chia 1995b, Gosselin 1997, Moran \& Emlet 2001). However, desiccation stress as well as thermal stress are generally greater at sites protected from wave action (Dayton 1971, Etter 1988, Dahlhoff et al. 2001), and thus would not explain the increasing hatching size of $N$. ostrina with wave exposure. Given that levels of desiccation stress occurring in intertidal habitats at low tide are lethal to the full range of sizes at which $N$. ostrina hatches (Gosselin \& Chia 1995b, Gosselin 1997), the effects of this mortality factor may be neutral with regard to hatching size (Moran \& Emlet 2001)

Identifying the environmental factors that control hatching size is not straightforward. This may be because the average hatching size of a population is determined by several selective pressures that act, and possibly interact, to influence initial juvenile size, and because the evolution of initial size can also be influenced by benefits occurring later in life (Smith \& Fretwell 1974, Marshall et al. 2003) and by constraints on the parent that are not adaptive for the early juvenile (McGinley et al. 1987). Discovering which factors control interpopulation variation in initial juvenile size in benthic marine invertebrates will undoubtedly require a much better understanding of the relative importance of factors causing early juvenile mortality; these are currently poorly understood. Deciphering the relative contribution of individual factors to the overall severity of an environment for the early juvenile is complex but worth the challenge, as the knowledge gained will considerably improve our understanding of the mechanisms controlling population dynamics, life history evolution, and the adaptive significance of early juvenile traits.

Acknowledgements. We thank M. Borthwick, L. Jones, and D. Pick for helping with field and laboratory work, as well as E. Boulding and T. Rawlings for comments on a previous version of the manuscript. Also thanks to the director and staff of the Bamfield Marine Sciences Centre for providing facilities, equipment and support during this study. The present study was conducted in compliance with the requirements of the Animal Research Ethics Committee of Thompson Rivers University and the Canadian Council of Animal Care. This work was supported by NSERC and SAC grants to L.A.G. 


\section{LITERATURE CITED}

Boulding EG (1990) Are the opposing selection pressures on exposed and sheltered shores sufficient to maintain genetic differentiation between gastropod populations with high intermigration rates? Hydrobiologia 193:41-52

Boulding EG, Hay TK (1993) Quantitative genetics of shell form of an intertidal snail-constraints on short-term response to selection. Evolution 47:576592

Boulding EG, Van Alstyne KL (1993) Mechanism of differential survival and growth of two species of Littorina on a wave exposed and on protected shores. J Exp Mar Biol Ecol 169:139-166

Boulding EG, Holst M, Pilon V (1999) Changes in selection on gastropod shell size and thickness with wave exposure on Northeastern Pacific shores. J Exp Mar Biol Ecol 232: 217-239

Carballo M, Garcia C, Rolan-Alvarez E (2001) Heritability of shell traits in wild Littorina saxatilis populations: results across a hybrid zone. J Shellfish Res 20:415422

Crothers JH (1983)Variation in dog-whelk shells in relation to wave action and crab predation. Biol J Linn Soc 20:85B102

Dahlhoff EP, Buckley BA, Menge BA (2001) Physiology of the rocky intertidal predator Nucella ostrina along an environmental stress gradient. Ecology 82:2816-2829

Dayton PK (1971) Competition, disturbance and community organization: the provision and subsequent utilization of space in a rocky intertidal community. Ecol Monogr 41: 351-389

Emlet RB, Hoegh-Guldberg O (1997) Effects of egg size on postlarval performance: experimental evidence from a sea urchin. Evolution 51:141-152

Emlet RB, Sadro SS (2006) Linking stages of life history: how larval quality translates into juvenile performance for an intertidal barnacle (Balanus glandula). Integr Comp Biol 46:334-346

Etter RJ (1988) Physiological stress and color polymorphism in the intertidal snail Nucella lapillus. Evolution 42:660-680

Etter RJ (1989) Life history variation in the intertidal snail Nucella lapillus across a wave-exposure gradient. Ecology 70:1857-1876

Etter RJ (1996) The effect of wave action, prey type, and foraging time on growth of the predatory snail Nucella lapillus (L). J Exp Mar Biol Ecol 196:341-356

Gosselin LA (1994) The ecology of early juvenile Nucella emarginata (Gastropoda, Prosobranchia): Are hatchling snails simply small adults? $\mathrm{PhD}$ dissertation, University of Alberta, Edmonton

Gosselin LA (1997) An ecological transition during juvenile life in a marine snail. Mar Ecol Prog Ser 157:185-194

Gosselin LA, Chia FS (1994) Feeding habits of newly hatched juveniles of an intertidal predatory gastropod, Nucella emarginata (Deshayes). J Exp Mar Biol Ecol 176:1-13

Gosselin LA, Chia FS (1995a) Distribution and dispersal of early juvenile snails: effectiveness of intertidal microhabitats as refuges and food sources. Mar Ecol Prog Ser 128: 213-223

Gosselin LA, Chia FS (1995b) Characterizing temperate rocky shores from the perspective of an early juvenile snail: the main threats to survival of newly hatched Nucella emarginata. Mar Biol 122:625-635

Gosselin LA, Qian PY (1997) Juvenile mortality in benthic marine invertebrates. Mar Ecol Prog Ser 146:265-282

Kitching JA (1976) Distribution and changes in shell form of Thais spp. (Gastropoda) near Bamfield, B.C. J Exp Mar Biol Ecol 23:109-126

Leigh EG, Pain RT, Quinn JF, Suchanek TH (1987) Wave energy and intertidal productivity. Proc Natl Acad Sci USA 84:1314-1318

Marko PB, Palmer AR, Vermeij GJ (2003) Resurrection of Nucella ostrina (Gould, 1852), lectotype designation for $N$. emarginata (Deshayes, 1839), and molecular genetic evidence of Pleistocene speciation. Veliger 46:77-85

Marshall DJ, Keough MJ (2003) Effects of settler size and density on early post-settlement survival of Ciona intestinalis in the field. Mar Ecol Prog Ser 259:139-144

Marshall DJ, Keough MJ (2005) Offspring size effects in the marine environment: a field test for a colonial invertebrate. Aust Ecol 30:275-280

Marshall DJ, Bolton TF, Keough MJ (2003) Offspring size affects the post-metamorphic performance of a colonial marine invertebrate. Ecology 84:3131-3137

McGinley MA, Temme DH, Geber MA (1987) Parental investment in offspring in variable environments - theoretical and empirical considerations. Am Nat 130:370-398

Menge BA (1983) Components of predation intensity in the low zone of the New England rocky intertidal region. Oecologia 58:141-155

Moran AL (1999) Size and performance of juvenile marine invertebrates: potential contrasts between intertidal and subtidal benthic habitats. Am Zool 39:304-312

Moran AL, Emlet RB (2001) Offspring size and performance in variable environments: field studies on a marine snail. Ecology 82:1597-1612

Palmer AR (1985) Adoptive value of shell variation in Thais lamellosa: effect of thick shells on vulnerability to and preference by crabs. Veliger 27:349-356

Phillips NE (2002) Effects of nutrition-mediated larval condition on juvenile performance in a marine mussel. Ecology 83:2562-2574

Räsänen K, Laurila A, Merilä J (2005) Maternal investment in egg size: environment- and population-specific effects on offspring performance. Oecologia 142:546-553

Rawlings TA (1994) Encapsulation of eggs by marine gastropods: effect of variation in capsule form on the vulnerability of embryos to predation. Evolution 48:1301-1313

Rawlings TA (1995) Encapsulation of eggs by the rocky shore marine gastropod Nucella emarginata: costs and benefits of variation in capsule form. PhD dissertation, University of Alberta, Edmonton

Ray-Culp M, Davis M, Stoner AW (1999) Predation by xanthid crabs on early post-settlement gastropods: the role of prey size, prey density, and habitat complexity. J Exp Mar Biol Ecol 240:303-321

Rex MA, Etter RJ, Clain AJ, Hill MS (1999) Bathymetric patterns of body size in deep-sea gastropods. Evolution 53: 1298-1301

Rivest BR (1983) Development and the influence of nurse egg allotment on hatching size in Searlesia dira (Reeves 1846). J Exp Mar Biol Ecol 69:217-241

Robles CD, Alvarado MA, Desharnais RA (2001) The shifting balance of littoral predator-prey interaction in regimes of hydrodynamic stress. Oecologia 128:142-152

Shanks AL, Wright WG (1986) Adding teeth to wave action: the destructive effects of wave-bourne rocks on intertidal organisms. Oecologia 69: 420-428

Smith CC, Fretwell SD (1974) The optimal balance between size and number of offspring. Am Nat 108:499-506

Smith KN, Herrnkind WF (1992) Predation on early juvenile spiny lobsters Panulirus argus (Latreille): influence of size and shelter. J Exp Mar Biol Ecol 157:3-18

Sokal RR, Rohlf FJ (1981) Biometry, 2nd edn. WH Freeman, New York

Spight TM (1976a) Ecology of hatching size for marine snails. 
Oecologia 24:283-294

Spight TM (1976b) Hatching size and the distribution of nurse eggs among prosobranch embryos. Biol Bull (Woods Hole) 150:491-499

Stearns SC (1992) The evolution of life histories. Oxford University Press, Oxford

Thiyagarajan V, Harder T, Qiu JW, Qian PY (2003) Energy content at metamorphosis and growth rate of the early juvenile barnacle Balanus amphitrite. Mar Biol 143:543-554

Tsai ML, Dai CF (2001) Life history plasticity and reproductive strategy enabling the invasion of Ligia exotica

Editorial responsibility: Howard Browman (Associate Editorin-Chief), Storebø, Norway
(Crustacea: Isopoda) from the littoral zone to an inland creek. Mar Ecol Prog Ser 210:175-184

Vermeij GJ (1978) Biogeography and adaptation-patterns of marine life. Harvard University Press, Cambridge, MA

Walker SE, Rypstra AL, Marshall SD (2003) The relationship between offspring size and performance in the wolf spider Hogna helluo (Araneae: Lycosidae). Evol Ecol Res 5: $19-28$

Zar JH (1999) Biostatistical analysis, 4th edn. Prentice Hall, Englewood Cliffs, NJ

Submitted: June 13, 2006; Accepted: November 1, 2006 Proofs received from author(s): May 23, 2007 